\title{
Urdimento
}

Revista de Estudos em Artes Cênicas E-ISSN: 2358.6958

\section{Valeska Gert e Marcelo Evelin: Morrer em dança}

Volmir Cordeiro

\section{Para citar este artigo:}

CORDEIRO, Volmir. Valeska Gert e Marcelo Evelin:

Morrer em dança. Urdimento, Florianópolis, v. 3, n. 39, nov./dez. 2020.

DOI: http:/dx.doi.org/10.5965/14145731033920200214

Este artigo passou pelo Plagiarism Detection Software | iThenticate 


\title{
Valeska Gert e Marcelo Evelin: Morrer em dança1
}

\author{
Volmir Cordeiro
}

\begin{abstract}
Resumo
A política é inteiramente ativa na construção das relações entre o poder e a morte, e toma medidas diárias que decidem como morremos, quem morre, quando e por quais razões. Antes e para além do Covid-19, o poder político se apropria da morte para fazê-la objeto da sua gestão e isso é decisivo na condução das nossas vidas. Mas como a dança politiza as relações entre vida, poder, corpo e morte? Através de quais procedimentos estéticos a dança aborda um corpo político e transforma o olhar sobre o que é uma vida e como reconhecê-la? A partir de duas cenas - uma da cabaretista alemã Valeska Gert, no seu solo Morte (1925), e outra do coreógrafo brasileiro Marcelo Evelin, Batucada (2014) - o presente artigo destaca algumas contribuições da dança para a reflexão dos mecanismos sociais produtores da vida e reconhecedores do que torna um corpo vivo.
\end{abstract}

Palavras-chave: Morte. Dança. Vida. Valeska Gert. Marcelo Evelin. Batucada. Arte política.

\section{Valeska Gert and Marcelo Evelin: To die in dance}

\begin{abstract}
Politics is entirely active in the construction of relations between power and death and continuously takes action that determine how we die, who dies, when and for which reasons. Before and beyond Covid-19, political power appropriates death to make it an object of its management, determining the course of our lives. But how does dance politicize the relationships between life, power, body and death? Through which aesthetic procedures does dance approach a political body and transform the view of what life is and how to recognize it? Based on two scenes - one by the German cabaretist Valeska Gert, in her solo Death (1925), and another by the Brazilian choreographer Marcelo Evelin, Batucada (2014) - this article highlights some contributions of dance to the reflection of the social mechanisms that produce life and that recognize what makes a body alive.
\end{abstract}

Keywords: Death. Dance. Life. Valeska Gert. Marcelo Evelin. Batucada. Political art.

\footnotetext{
${ }^{1}$ Conferência online para o Clube de Espectadores da Associação Materiais Diversos, situado no distrito de Santarém, Portugal, dia 25 de junho de 2020.

${ }^{2}$ Artista-pesquisador, doutor em dança pela Universidade Paris VIII, França. Bailarino e coreógrafo, dirige a Companhia Donna Volcan apresentando suas criações mundo afora. Recentemente publicou o livro Excorpo, extensão da sua tese. volmir.c@gmail.com
} 


\section{Valeska Gert et Marcelo Evelin : Mourir en danse}

\section{Résumé}

La politique est entièrement active dans la construction des relations entre le pouvoir et la mort, et prend des mesures en permanence qui décident sur comment on meurt, qui meurt, quand et pour quelles raisons. Avant et au-delà du Covid-19, le pouvoir politique s'approprie de la mort pour en faire l'objet de sa gestion, et cela est déterminant dans la conduite de nos vies. Mais comment la danse politise les relations entre vie, pouvoir, corps et mort? À travers quelles procédures esthétiques la danse devient capable d'aborder un corps politique et de transformer le regard sur ce qui est une vie et comment la reconnaitre? C'est à partir de deux scènes l'une de la cabarettiste allemande Valeska Gert, dans son solo Mort (1925), et l'autre du chorégraphe brésilien Marcelo Evelin, Batucada (2014) - que ce texte s'engage à préciser certaines contributions de la danse pour la réflexion autour de mécanismes sociaux producteurs de vie et de la reconnaissance de ce qui fait un corps vivant.

Mots-clés: Mort. Danse. Vie, Valeska Gert. Marcelo Evelin. Batucada. Art politique. 


\section{Rondas de vida e de morte}

Os jornais, as redes sociais, os grupos de amigos compartilham e atualizam os números de mortos pelo Covid-19. Sabemos que um jovem negro é morto a cada 23 minutos. A cada 7 horas uma mulher é morta por ser mulher. O Brasil é o país que mais mata LGBTQI+ do mundo. A polícia brasileira é a que mais mata, se mata e é morta. É perda atrás de perda. Vivemos uma vida de mortes injustas e inaceitáveis. Não há paz. A morte ronda, persegue, caça, assalta e se encarna nos corpos que penam para ser reconhecidos como vidas, ainda que estejam vivos. A destruição e a negligência não têm limites; a morte não é o limite, mas sim o ponto de partida de um projeto mortífero meticulosamente construído para declarar e produzir o desaparecimento de vida tornadas, intencionalmente, precárias. A precarização é justamente o afastamento de todos os mecanismos de proteção da destruição da vida até o ponto em que estar desprotegido e vulnerável se torne parte integrante do processo e da condição de estar vivo.

A ação política contemporânea de "exercer controle sobre a mortalidade e definir a vida como implementação e manifestação do poder" (Mbembe, 2018, p. 5), organizando uma política pautada na produção de morte - e orientada pelo racismo - faz parte do que Achille Mbembe chama de necropolítica. Em outras palavras, trata-se de uma política de morte que se "comprometeria a civilizar os modos de matar e atribuir objetos racionais no ato de matar" (Mbembe, 2018, p. 33). Nesse cenário, algumas populações são consideradas muito vivas enquanto outras ficam passíveis de morte porque o poder soberano e o biopoder assim determinam. Quando a vida e a morte são anonimizadas, perdem importância, sentido e significância, um regime de sobrevida se instala e faz da mortalidade de muitos uma negligência aceitável. Entretanto, a vida e a morte de qualquer ser na terra conta porque estamos inexoravelmente inscritos num circuito de afetos sociais e interdependentes.

Porque temos obrigações éticas e sociais a respeito de todos com quem compartilhamos a terra, somos interpelados a repensar os modos de vida os modos de morte produzidos e estimulados socialmente. A vida só é ou só se torna 
precária através das organizações políticas de privação que decidem quais vidas podem ser vividas e quais vidas "devem" ser destruídas. Pensar em corpo político é pensar nas potências mortíferas que circulam aterrorizando certas vidas e seus direitos. Para citar Judith Butler (2010, p. 20): "o valor da vida só aparece nas condições onde a perda importa"3. Butler coloca em questão as lágrimas choradas diante de uma morte e a fundamental importância do luto, são expressões de perda que destacam o valor da vida. Mas para que estas expressões manifestem este valor, as vidas precisam ser olhadas, cuidadas, testemunhadas, apreendidas e reconhecidas. E é aqui que surge a dança, com a sua especificidade em gerar cenas, gestos, olhares, e de apresentar corpos vivos jogando, simulando e encenando versões de vida e de morte.

Nessa paisagem de notificações, cenas e lives sobre mortes, escolhi duas danças para pensar em vitalidade e no ato de morrer como gesto dançado. A primeira é Morte, peça da cabaretista alemã Valeska Gert, filmada por Suzy Byk em 1925․ A segunda é a última parte, a última cena, os últimos quinze minutos formando uma parcela feroz da performance Batucada, do coreógrafo piauiense Marcelo Evelin, assistida em 20145. A partir dessas duas cenas, como pensar consciências de mortalidade através da dança? Será a dança uma forma no mundo especializada em abordar a condição do vivo?

\section{Valeska Gert em Morte}

Valeska Gert (1892 - 1978) descreve na sua autobiografia (2004, p.70), com vigorosa síntese e bastante intensidade, Morte: dança abstrata, dança de expressão, pantomima dançada, criada por ela e filmada por Suse Byk em 1925.

Eu estou imóvel dentro de uma longa túnica preta sobre um pódio cruamente iluminado. Meu corpo tensiona com lentidão, o combate

\footnotetext{
${ }^{3}$ La valeur de la vie n'apparaît que dans des conditions où la perte importerait. (Tradução nossa)

${ }^{4}$ Acesso disponível em : https://www.numeridanse.tv/en/dance-videotheque/tanzerische-pantominen 


\section{Urdimento}

começa, os punhos se apertam cada vez mais fortemente, os ombros se curvam, o rosto se torce - efeito do sofrimento, do tormento. Esse sofrimento se torna insuportável, a boca se abre longamente para um grito mudo. Eu jogo a cabeça para trás, os ombros, os braços, as mãos e todo o corpo se petrifica. Eu tento me defender. Absurdo. Eu fico imóvel durante alguns segundos, uma coluna de sofrimento. Depois, a vida lentamente deixa o meu corpo, e bem devagar o meu corpo relaxa. O sofrimento se acalma, a boca amolece, os ombros caem, os braços ficam flácidos, as mãos. Eu sinto a rigidez dos espectadores na sala, eu quero consolá-los, um reflexo de vida desliza no meu rosto, e de muito longe emerge um sorriso. E então ele cede bruscamente, as bochechas relaxam, a cabeça cai rapidamente, uma cabeça de boneca. Fim. Foi. Estou morta. Silêncio de morte. Ninguém ousa respirar na sala. Estou morta. ${ }^{6}$

Figura 1 - Fred Hildenbrandt

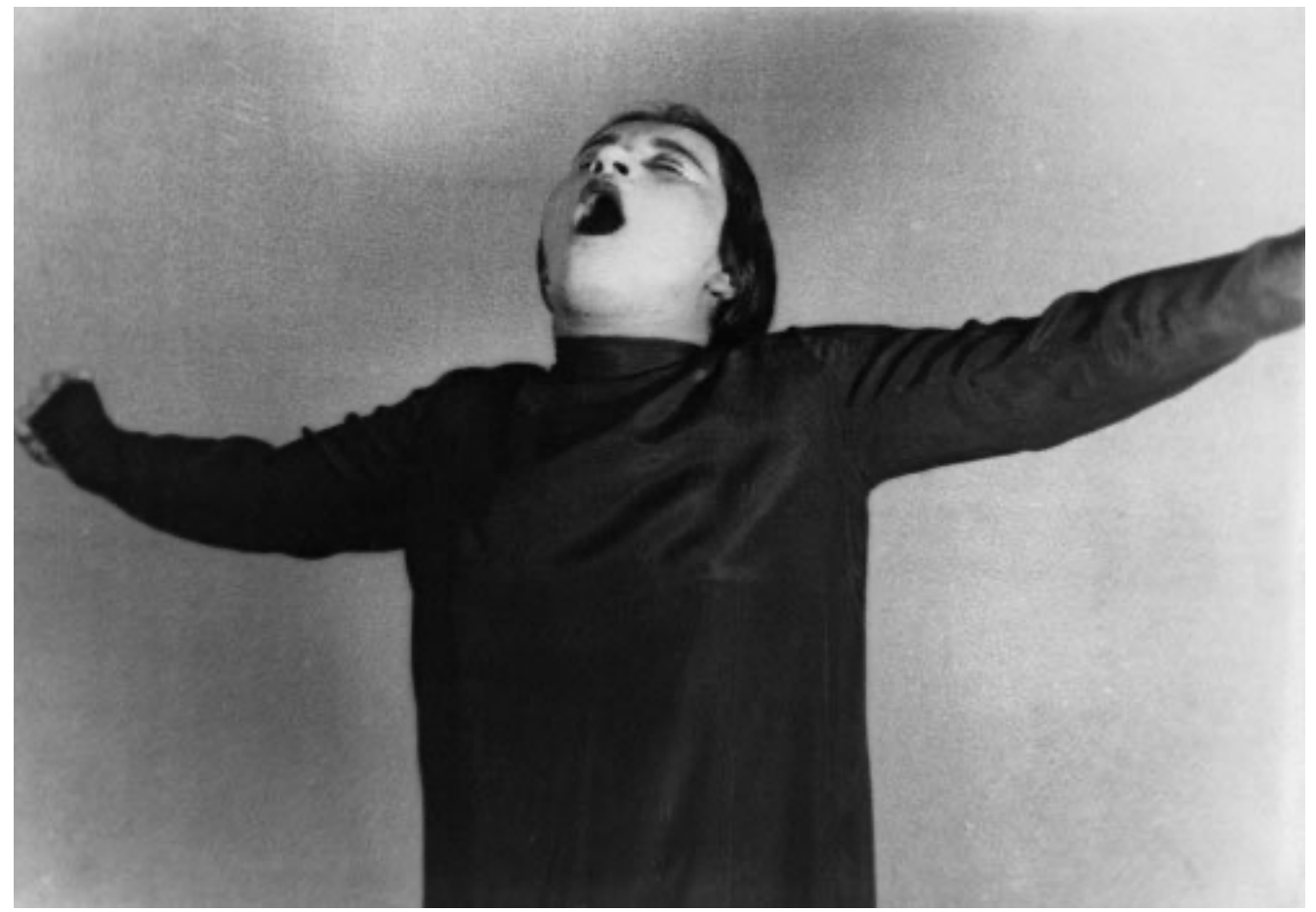

Die Tänzerin Valeska Gert, Stuttgart, Hädecke, 1928, p. 65

\footnotetext{
6 Je me tiens immobile dans une longue tunique noire sur le podium crûment éclairé. Mon corps se tend avec lenteur, le combat débute, les poings se serrent de plus en plus fermement, les épaules se courbent, le visage se tord sous l'effet de la souffrance, du tourment. Cette souffrance devient insupportable, la bouche s'ouvre largement pour un cri muet. Je rejette la tête en arrière, épaules, bras, mains et tout le corps se pétrifie. Je tente de m'en défendre. Absurde. Je me tiens là immobile pendant des secondes, une colonne de souffrance. Puis la vie lentement quitte mon corps, très lentement il se détend. La souffrance faiblit, la bouche s'amollit, les épaules tombent, les bras deviennent flasques, les mains. Je sens la rigidité des spectateurs dans la salle, je veux les consoler, un reflet de vie se glisse sur mon visage, déjà, de très loin, émerge un sourire. Puis voilà qu'il s'affaisse brusquement, les joues se relâchent, la tête chute rapidement, une tête de poupée. Fini. En allée. Je suis morte. Silence de mort. Personne n'ose respirer dans la salle. Je suis morte. (Tradução nossa)
} 
Com grande simplicidade e uma economia de meios, Valeska Gert está só em cena no momento em que dança o gesto universal de morrer. Em menos de dois minutos, o "combate" se dá em uma sequência de movimentos precisos: um sobressalto, um fechar os olhos, uma contorção, um grito mudo, uma petrificação, uma tentativa de defesa, uma imobilidade e uma concessão vagarosa. Entre uma "coluna de sofrimento" e um "reflexo de vida", Gert dança a escuta do próprio corpo dando vida e passagem para a (própria) morte. A Morte consiste em deixarse tomar por uma força interna que parece vir de fora e que prende a respiração, que comprime a carne, que ataca a concretude do corpo, inebriando-o de finitude através de um relaxamento profundo que deixa o rosto sorrir misteriosamente.

Solista, performer, atriz, coreógrafa, cabaretista, escritora, nascida na Alemanha, em uma família judia, Valeska Gert fez mais de trinta solos antes de compor a Morte. Dançou também o nascimento, o amor, a humildade, entre outras abstrações. Figura emblemática da modernidade em dança na Alemanha, ficou reconhecida pela extravagância grotesca, êxtase e desbunde irreverentes. Gostava de dançar tipos, personagens, caracteres, misturando e ultrapassando as fronteiras entre a dança, o teatro e a performance. Foi para Bertolt Brecht o que ele aspirava para o seu teatro épico? ${ }^{7}$ Foi para Meyerhold, a bailarina bioenergética. Atuou para Federico Fellini (Julieta dos Espiritos, 1965). Na sua autobiografia escreve que precisa de um punhado de lixo assim como de faíscas para criar.

Quando o vídeo começa, a impressão é de que Gert já estava ali há muito mais tempo, à espera da morte que chega para ela enquanto alteridade forte e inevitável. Como gastar a vida numa energia de morte? Como dançar a certeza de desaparecer e a fatalidade da vida que urge em ser vivida com intensidade? "Não tem graça, não tem como escapar, um dia será o meu... Se tudo passa tão rápido, então é preciso que eu viva muitas coisas igualmente rápido, com bastante densidade. Isso é claro para mim"8 ( Gert, 2004, p. 48), escreve Gert, que cria Morte

7 "Mas Bertolt Brecht, que também me assistiu, disse: o que você faz, é o que eu quero conseguir fazer". (Mais Bertolt Brecht, qui m'avait aussi regardée, dit pour sa part: "Ce que vous faites là, c'est ce à quoi je veux aboutir). (Gert, 2004, p.61). (Tradução nossa)

${ }^{8}$ Il n'y a pas de grâce, il n'y a pas d'échappatoire. Un jour, c'en sera fini de moi. [...]. Si tout est si vite passé, alors il me faut vivre beaucoup de choses également vite, de façon très dense. Voilà qui m'était clair. (Tradução nossa) 
no pós primeira guerra mundial, quando relata não haver mais ruínas, mas só um amontoado de pedras sem passado nem restos. Seu desejo era dançar "energizada" pelas "vidas arruinadas", cansadas, despedaçadas, perseguidas, tais como os marginais, as prostitutas, os prisioneiros ou outras figuras miseráveis. Dançar, para ela, é fazer justiça com o próprio corpo, no ato de dar forma e imagem para essas vidas que hoje nos habituamos a chamar de vidas precarizadas.

A historiadora em dança Isabelle Launay escreve que Gert "não percebe o mundo a partir de um princípio de colapso depressivo, melancólico e nostálgico, mas seguindo um princípio de explosão e de expansão necessário"10 (2014, p. 53). Situando a criação de Gert no pós-guerra de um cenário de destruição, Launay reforça a força caótica da sua dança como "máquina explosiva, excêntrica", associada às necessidades externas com as quais Gert se sensibiliza, e procura contato com uma certa urgência, como, por exemplo, a de encontrar-se com o público. Gert (2004, p. 72) escreve:

Os meus espectadores, eu posso assustá-los como acalmá-los, repelilos assim que atraí-los, eu posso também fazer com que eles me amem. Realmente, eu posso isso também. Eu jogo com eles como eu jogo com os homens na rua. ${ }^{11}$

Nas palavras de Philippe Ivernel (2004, p.16), "a sua poética, longe de todo formalismo, se alimenta dos extremos da existência, de onde pode vir uma energia máxima suscitada, de um lado, pelo desejo e, de outro, pela confrontação com a morte"12. Gert (2004, p. 21) definia a "dança grotesca" como a síntese, em único gesto, da presença de extremos. Para ela, essa forma de dança constitui o "símbolo verídico" de uma realidade pautada na instabilidade das garantias e na

9 Tradução nossa para "vies crevées".

${ }^{10}$ Aussi ne perçoit-elle pas le monde à partir d'un principe d'effondrement dépressif, mélancolique et nostalgique, mais suivant un principe d'explosion et d'éclatement nécessaire. (Tadução nossa)

${ }^{11}$ Mes spectateurs, je pouvais les effrayer et les apaiser, les repousser et les attirer, oui, je pouvais même obtenir qu'ils m'aiment. Vraiment, je pouvais cela aussi. Je jouais avec eux comme avec les hommes dans la rue. (Tradução nossa)

${ }^{12}$ Reste que sa poétique, loin de tout formalisme, vient se nourrir aux extrêmes de l'existence, d'où peut venir l'énergie maximale suscitée, d'un côté, par le désir et, de l'autre, par la confrontation avec la mort. (Tradução nossa) 
problematização das "formas fixas e certas da criação"13. Há também em Batucada uma maneira específica de convocar extremos, e de performar aquilo que para Evelin está no seio da criação: "indisciplinaridade (pensamento selvagem), insubmissão, resistência, insistência, continuidade (com interrupção) produto (mesmo que seja processo)... é mover montanhas, fazer existir, fazer existir, fazer existir"14.

\section{A última cena de Batucada, de Marcelo Evelin ${ }^{15}$}

Marcelo Evelin (1962) nasceu em Teresina, Piauí. Ele faz parte de um grupo de coreógrafos brasileiros como Lia Rodrigues, Cristian Duarte, Thiago Alexandre ou o Coletivo Terreiro Coreográfico que inscrevem seus projetos artísticos no coração de contextos sociais, promovendo formas de implicação territorial a fim de gerar encontros sociais e transformações no acesso à dança contemporânea. Professor, diretor de Companhia - a Demolition Incorporada, criada em Nova York, em 1995 - é também curador, coreógrafo e bailarino. Estudou com os coreógrafos Klauss Vianna e Angel Vianna antes de ser estagiário por nove meses na Companhia da Pina Bausch e aluno do coreógrafo americano Mark Tompkins, esse que por sua vez, homenageou Valeska Gert em uma de suas Hommages (/cons, 1998). Entre muitas das obras de Evelin, há ainda as imperdíveis Matadouro (2010), De repente fica tudo preto de gente (2012) e Dança Doente (2017), igualmente potentes para continuar imaginando como morrer em dança (respectivamente: o bandidobanido, o desaparecimento em massa e o corpo em crise/luto).

${ }^{13}$ Hoje justamente, onde todos os valores estabelecidos se deslocam, onde quase tudo aquilo que parecia constituir um sentimento e uma inteligência garantidos se tornam problemáticos, hoje onde uma vontade cultural comum não se mantém mais em formas fixas e certas da nossa criação - a dança grotesca, que resume em um único gesto a imediatez dos extremos prontos para explodir, me parece ser um símbolo verídico do nosso tempo. - (Aujourd'hui justement, où toutes les valeurs établies se disloquent, où presque l'ensemble de ce qui paraissait constituer un sentiment et une intelligence assurés redevient problématique, aujourd'hui donc où une volonté culturelle commune ne maintient plus dans des formes fixes et certaines notre création - la danse grotesque, qui résume en un même geste immédiatement les extrêmes en passe d'exploser, me semble être un symbole véridique de notre temps). (Tradução nossa)

14 Ver Ovo, conferência-performance, de Marcelo Evelin, vídeo de Jell Carrone, no site https://www.demolitionincorporada.com/ovo projeto subvencionado pelo Rumos Dança 2012-2014.

15 Uma abordagem mais ampla da totalidade do espetáculo foi feita para a minha tese de doutorado e, em seguida, para a sua publicação intitulada Ex-Corpo (Edições Carnets, Centre National de la Danse, 2019). 
Sobre o que é Batucada, que estreou em 2014, no KunstFestivaldesArts, em Bruxelas, Marcelo Evelin anuncia:

\begin{abstract}
BATUCADA é um desfile anti-Olímpico preso/paralisado/travado no tempo e no espaço. Uma espécie de Parada em suspensão, que vai funcionar como uma re-organização de seus movimentos e metas, para recarregar e disseminar, no espaço público ocupado, um poder simbólico participativo e comum. A intervenção coreográfica vai servir para demonstrar, protestar e/ou celebrar a comunidade humana, considerando diversidade e antagonismo como parte essencial de uma revolução democrática. O ritmo transita entre a festa e o protesto num ritual que expõe a relação conflitante entre uma coletividade quase tribal e a subjetividade dos indivíduos. O batucar em objetos cotidianos desmancha fronteiras entre espectador e artista, provocando reflexões sobre a pulsão do homem na sociedade contemporânea.

[...]

BATUCADA é um rito urbano, uma procissão civil, um desfile alegórico de um circo hipnótico, um carnaval pagão, uma festa bárbara, um protesto mascarado, a explosão de uma revolução interior ${ }^{16}$.
\end{abstract}

Tentativa de descrever Batucada: entrando em um espaço imenso (teatro, museu, garagem, usina), os espectadores encontram balões vermelhos em forma de coração pendurados cheios de gás que os mantém no alto, colados ao teto. Os fios desses balões ficam suspensos, e os espectadores podem pegá-los e brincar fazendo-os subir e descer. Os corações no teto - representação de um espaço afetivo suspenso - atraem o olhar para cima que delimita e enquadra o que se passa no baixo, aqui em baixo, com esse "povo (do) baixo", no presente do chão cimentado onde a performance acontece. Os cinquenta performers se distinguem pelo uso de máscaras e das panelas, latas e tampas que utilizam com suas baquetas. A máscara faz alusão à Catirina, personagem do nordeste do Brasil, lenda folclórica que trata da história da morte e ressurreição de um boi. Ela é feita de um tecido preto com dois furos para os olhos e um terceiro para a boca, mais um nariz grande, vermelho, em forma de cone apontando para a frente. Os performers, em um primeiro tempo vestidos, se aproximam cruamente do público; estão no meio, longe, perto, no entorno dos espectadores. Não há lugar determinado para sentar, os espectadores têm que tomar posição das suas

${ }^{16}$ Disponível em https://www.demolitionincorporada.com/batucada 
posturas corporais. A sensação de um começo de performance acontece quando os performers começam uma dança frenética, entre o samba, o rap, a salsa, a dança de rua; uma dança festiva incorporando o convulsivo, o trepidante, o chacoalhar, o anárquico, o espasmódico, a contorção, o improviso. Nessa dança, eles vão pouco a pouco se despindo, "enudecendo". A batucada começa e os corpos se misturam; um ritmo, uma musicalidade aparece. Aí, um passeio pelas bordas do espaço. Depois uma dança em um dos cantos do espaço com luzes ao fundo. Uma sensualidade forte esparramada no espalhamento dos corpos na totalidade do espaço. Alguns espectadores se misturam à experiência e, nus ou quase nus, começam a dançar. Depois, uma grande linha, performers lado a lado, expostos. Cada vez mais uma forma de "nós" começa a ser desenhada: um "nós nus". Corpos iluminados, visíveis, barulhentos, singulares.

O desejo por uma coletividade viva organiza e conduz uma hora e meia de performance. O princípio que ativa a relação entre os corpos é bastante simples: um sorteio com os nomes dos performers para saber quem deve ficar ao lado de quem do início ao fim da Batucada. A nudez progressiva acentua o caráter festivo e vivo de ir pouco a pouco alargando a possibilidade de um comum feito do "nós, performers" com o "nós, espectadores". A nudez não é só a afirmação do êxtase coletivo como uma forma de renúncia do ser isolado, mas ela é, sobretudo, uma questão de aparecer corporalmente. Esse aparecer se transforma intensamente em se deixar reconhecer, gerando assim uma cena entre os corpos múltiplos que, se olhando pelos furos míseros da máscara, acabam instalando o reconhecimento mútuo de se perceber como vidas.

Mas é à última cena de Batucada que eu gostaria de me ater precisamente; sabendo ser impossível negligenciar tudo aquilo que a antecede fiz questão de descrever rapidamente a sua tão preciosa atmosfera inicial. No final, depois do espaço já ter sido atravessado de muitas formas, gerando desenhos e configurações diversas; depois de uma forma de insurreição ter ocorrido conduzida pela proliferação de afetos alegres e os seus contágios no entre dos corpos reunidos; depois de um terreno comunitário ter cultivado ligações, sons, toques, suores e faíscas de comum; depois de uma energia carnavalesca ter 
suspendido uma certa ordem e instaurado uma conversação entre os corpos sem preocupação consequencial das suas ações, através de relações provisórias e acaloradas, desordenando as fronteiras espaciais; os performers conduzem os espectadores até a saída do espaço. Ali no passo da porta, no limite entre o espaço da performance e a rua, na ponte entre o dentro e o fora, os performers deitam a barriga contra o chão. Os espectadores, alguns primeiramente bloqueados, se veem no exercício de encontrar uma saída que não seja a de "passar por cima" daqueles corpos. Outros, já bem mais a vontade e desenvoltos, encontram microbrechas para pisarem, atravessando a multidão de corpos nus deitados, até chegarem do outro lado. Os performers, imóveis no chão, não reagem àqueles que descuidadamente pisam sobre eles e deixam de ver a ação bruta que executam.

Figura 2 - Captura de tela do Teasear de Batucada, na sua estreia, no Kunstensfestivaldesarts

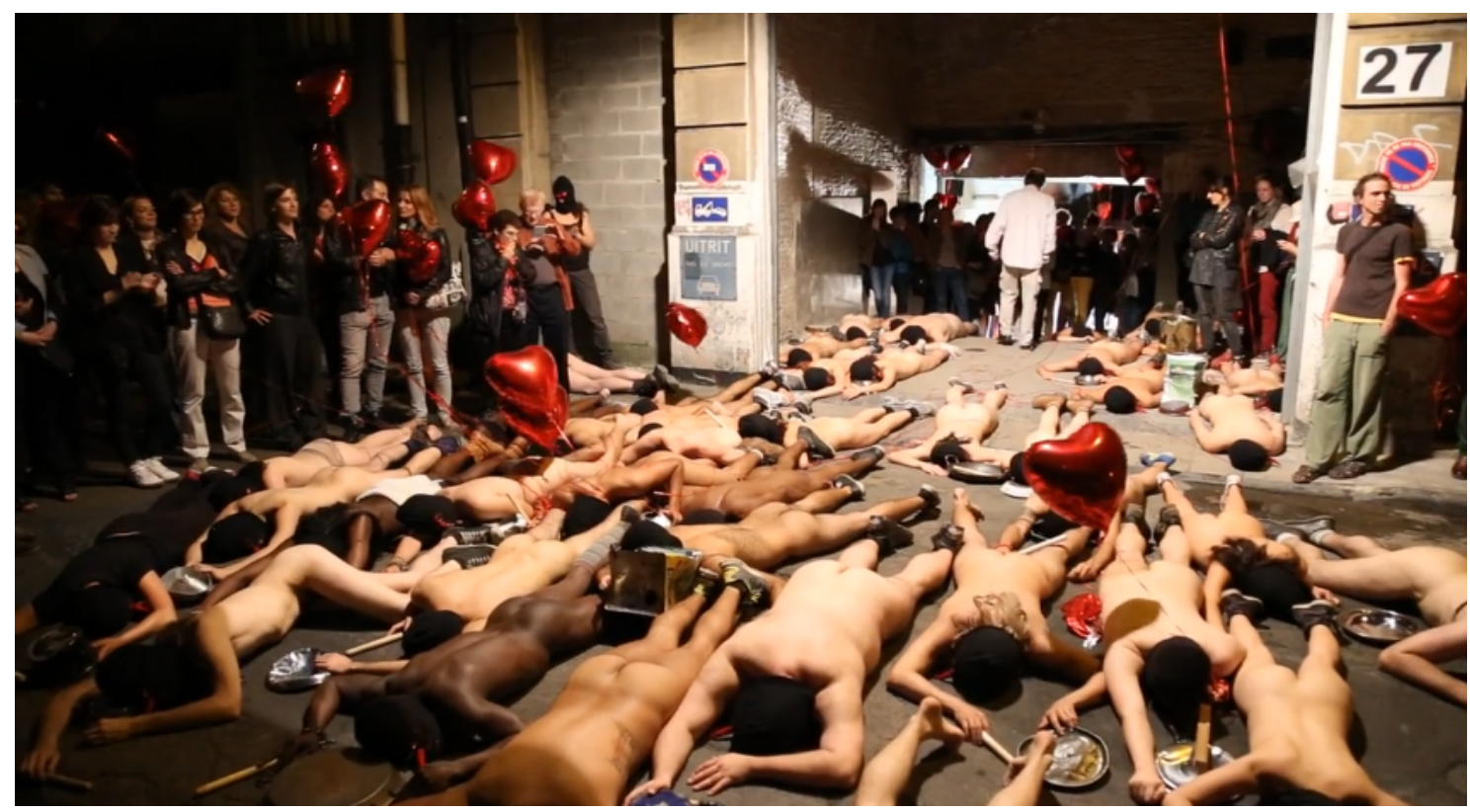

Dos balões-corações suspensos no alto do espaço revelando uma inalcançável capacidade de afeto, pontuando o início de Batucada, passamos para o seu fim rasteiro e visível através da "nudez baixa" de uma multidão que se performa achatada, silenciada, morta. Como apreender essa imagem final de vulnerabilidade, dos corpos deitados no chão, depois de tanta vitalidade dançada? 
Como receber esses corpos deitados? Para esta cena final, há a leitura possível de um grito pedindo apoio, de um gesto de urgência coletiva contra a ameaça e o perigo de desaparecer e ver a vida interrompida.

O que pensar dos espectadores que, bloqueados diante de tal cena, se apressam em encontrar uma solução: aplaudir para marcar o fim da performance ou sair pisoteando os corpos para se "ver livre" do desafio ético posto por tal imagem? Estariam eles impelidos por uma urgência em salvar seus próprios corpos e suas próprias peles de uma tomada de posição radical diante da vulnerabilidade do outro? Confrontar-se com o surgimento de uma posição é, ainda mais no término da performance, incorporar a potência do espectador como um agente que performa ao produzir relações de comunidade com aquilo que vê, assumindo e suportando o gesto de emergir (e de morrer) com o outro.

Da vida e do privilégio da vitalidade, nós somos interpelados pela impossibilidade da vida e o seu assujeitamento. A vida e a potência indomável seguida da capacidade de coletivo atravessadas no antes dessa cena revela que a festa, o êxtase e a união, não têm, necessariamente, nada de contraditório com a submissão e a opressão; e que de um momento de extrema alegria podemos passar para uma cena de violência. Lembra-se com a obra de Evelin que há gente fazendo festa vendo corpos violentados. A morte, em Batucada, aparece então como o ponto final da performance enquanto despertar das nossas ligações, refazimento das conexões perdidas e lembrança de que a liberdade não é a ausência de obstáculos, mas a permanência no comum e a perseverança comunitária.

\section{Do que é preciso para fazer da morte uma cena}

Parto do pressuposto de que o corpo do bailarino acentua, reforça, sublinha e revigora o caráter exposto de todo corpo social. O corpo, em cena e fora dela, está exposto ao Outro, e o Outro é tudo aquilo que participa do fazimento, da construção e da formação do corpo enquanto realidade interdependente de tudo o que existe no onde ele está; que é a partir de onde ele existe como presença 
interligada às múltiplas sociabilidades. O corpo para existir não para de se articular e desarticular tomado por um processo de afirmação do que é preciso para existir enquanto corpo: linguagem, trabalho, criatividade, desejo, afeto, comunicação, sono, sonho, comida, abrigo, roupa, lazer, etc.

Valeska Gert precisa de concentração profunda e de um transe autoprovocado pelo fechamento intenso dos olhos que faz parte da sua estratégia coreográfica de mentir para si mesma que ela se transforma em morte. Marcelo Evelin precisa justapor o corpo produtivo do barulho, da festa, da aliança social pelo suor e o êxtase com o corpo assujeitado, deitado, bloqueando a passagem como um grito pela igualdade entre os corpos.

Os dois coreógrafos precisam primeiro entender o corpo como fragilidade e superfície precária, concebendo assim a vida como exposição permanente ao seu fim; depois precisam coreografar a chegada dessa força externa sobre a estrutura física, afetiva e social dos seus corpos. Na morte de Gert, perder a vida é ato de consentimento, é soltar a última respiração com grande prazer; é testemunhar, de dentro, a sua partida. Para o espectador, trata-se de testemunhar de fora o seu testemunho interior. Na cena final de Batucada, a morte é desafio para aqueles que precisam passar para sair do espaço e afirmar o fim da performance testemunhada de fora e associada à imagem dos corpos nus sujeitos à morte, no chão. Há uma dupla morte, o fim da performance e o fim daquelas vidas até então festivas. Para as duas mortes em Batucada, o espectador é convocado como testemunha, afirmando com isso o caráter performativo da violência gerada pela cena.

Tanto em Gert como em Evelin, há um mecanismo específico de construção gestual, coreográfica e imagética que organiza visualmente um corpo vivo e disponível a tornar-se um corpo morto. Pelo trabalho corporal e de intensificação de imaginários, as duas cenas permitem pensar a organização sensível da transição da vida para a morte - ativação de um princípio vital e o seu apagamento - construindo um espaço político de reflexão que se dá pelos modos como os corpos aparecem e se endereçam. 
Gert fecha os olhos e prende a respiração para marcar a transição da vida para a morte enquanto Marcelo Evelin vai despindo os performers e enriquecendo as proximidades entre os corpos para enaltecer a nudez como ausência de fronteira e intensificação da nossa fragilidade. Nas duas cenas, o corpo é o encontro da vida com a morte, e o gesto de morrer é o meio de evidenciar esse encontro. Morrer em dança consiste, no estudo desses dois casos, em intensificar a força da alteridade como uma multidão de interferências que entram em acordo com certas exigências coreográficas, produzindo modos singulares de dançar a morte.

\section{Modos de morte}

A vitalidade que as duas cenas carregam é de que o corpo está suscetível à morte, e que essa suscetibilidade na arte é escolhida, coreografada e interpretável. A dança cria visibilidade, quadros, gestos, formas, modos de expressão, determina caminhos de leitura e interpretação, e com isso conduz a versões, conclusões, perguntas e dúvidas. Isso só é possível porque existe enquadramento, cena, recepção, tornando possível a observação e as narrativas que daí surgem. Nesse sentido, pensar o gesto de morrer em dança coloca em questão a atividade das interpretações que traduzem em palavras as experiências de intérpretes, coreógrafos, bailarinos, críticos ou pesquisadores, não sem isso colocar nossos pensamentos e traduções à prova das problemáticas atreladas às formas de apreender a dança em política.

Gert é solista e dança a morte como ressonância do pós-guerra. Evelin convoca cinquenta pessoas dispostas a batucar e a dançar a morte como destino, passagem, condição e fundamento da vida precária enquanto condição de existência no contexto de um Brasil racista, desigual e machista ${ }^{17}$. Gert dança em

${ }^{17}$ Lembramos que Batucada estreia em 2014, ano da Copa do Mundo no Brasil; mas também dos movimentos anti-Copa, dos movimentos contra o aumento do preço da passagem de ônibus, da crise hídrica em São Paulo e da reeleição de Dilma Rousseff - para citar apenas alguns dos fatos mais importantes desse ano. 
cabaré$^{18}$, Evelin precisa de espaço sem nome, às vezes museu, às vezes teatro, às vezes galpã ${ }^{19}$. Gert estrutura uma ordem progressiva de movimentos; é levada por um élan inicial, um ápice e um relaxamento. Evelin pensa em "estações", poses-pausas: intervalos de lucidez que se rompem com eles mesmos para voltar ao frenesi de movimentos desordenados e caóticos. Gert acredita que uma dança só existe quando encontra o olhar do público. Evelin acredita que uma dança só existe quando roça voluntária e involuntariamente na pele exposta do espectador. Gert e Evelin destroem o "sério e arrogante" da Arte e ativam a subversão latente e manifesta do mundo. Gert aspira figuras do real e transforma-as em abstrações. Evelin estende o seu habitat real dando-lhe um acabamento estético (sensível, formal, receptivo), polindo-o com mais crueza, transformando-o em aberração.

Em Batucada, a cena final expõe os corpos reduzidos à uma "nudez última", o final da peça aludindo à última nudez de suas vidas ou das vidas consideradas sobreviventes nesse mundo facilitador de mortes para as vidas marginalizadas. Esses mesmos corpos antes barulhentos, ruidosos, móveis e festivos estão agora silenciados, abarrotados uns sobre os outros no chão, removidos dos seus impulsos e movimentos. A Batucada como forma de vida peculiar e intensificação do comum pelo êxtase do estar junto se converte em rebaixamento da existência e silenciamento dos corpos. Já na Morte, a delimitação cênica se dá pela autoafecção: Gert joga com o próprio corpo e a sua disposição em ser por ele afetado. Ela inventa para si um estímulo e uma excitação de morte, fazendo vibrar na sua materialidade carnal a presença de uma alteridade fictícia. Ela dança a perda da vida produzindo um apaziguamento intenso das forças do mundo que é o esvaziamento do que há nela, por dentro, revelando um espaço aberto, novo, para surgirem outras reverberações vitais. Gert e Evelin, para morrer, se despojam do que thes continham, e afirmam um combate com a morte como possibilidade de nascer de novo.

${ }^{18}$ O primeiro cabaré que fundou em 1932, se chamava "Cabeça de Bagre" (Tête de chou, em francês), em Berlim.

${ }^{19}$ Em 2009, passa a ocupar e a dirigir o Núcleo de Criação do Dirceu, no Bairro do Dirceu, em Teresina. O Núcleo era uma plataforma fundada por mais de vinte artistas e pesquisadores das artes performáticas e realizava suas atividades num antigo supermercado que virou o Galpão do Dirceu, um espaço para criação e circulação de espetáculos, entre outras atividades de formação. 


\section{A vitalidade do fora}

No caso deste estudo, o que interessa particularmente é olhar para essas duas obras como cenas de morte, performance de perdas e gestos dançados para desaparecer. Gestos estes que não acontecem sem o pressuposto de que não é a vida ela mesma que está em questão, mas aquilo que a condiciona e torna possível a sua existência e viabilidade, e que estas se materializam na vitalidade do corpo. Nesse sentido, concordo com Kunichii Uno (2007, p. 50):

A vida e o corpo são, no fundo, a mesma coisa. Mas para que assim seja, é preciso descobrir o corpo dentro de sua própria força de gênese, porque o corpo é esse único lugar existencial e ainda por cima político, no qual se empilham, se encolhem, se dobram, todas as determinações da vida. É o campo de batalha onde se cruzam as forças visíveis e invisíveis, a vida e a morte onde se encadeiam as redes, os poderes e os tráficos.

Uma perspectiva do corpo complementar a de Kunichii Uno, abordada pelas pesquisadoras Ana Cláudia Albano Vianna e Terezinha Petrúcia da Nóbrega (2019) - que também estabelecem um diálogo entre a dança e a morte através do ballet romântico, do expressionismo de Mary Wigman e do Butô ${ }^{20}$ e, apesar de tratar de um corpus diferente das obras coreográficas com as aqui postas em questão - é capaz de elucidar o que Gert cria com a Morte (ela mesma contemporânea de Wigman mas menos canonizada pela história oficial da dança), assim como Evelin, ao propor uma performance que pode ser sentida como "um campo de batalha" pela expressão de uma trama de afetos conflituosos.

Compreendemos que as obras de arte em dança, com as quais conversamos, realizam tramas coreográficas que revelam e são reveladas por corpos que expressam a visibilidade do humano corporal, espiritual, paradoxal, racional e poético, todos ao mesmo tempo, o tempo todo, todo o tempo num espaço único de concretude: o corpo que se faz e se refaz na existência.

${ }^{20}$ Respectivamente Giselle, ballet de muitas versões sendo a mais conhecida a de Marius Petipa, Chamado da Morte, de Mary Wigman e UTT, coreografada por Carlota Ikeda e Ko Murobushi. 
O "corpo-vida" de Batucada, no seu constante fazimento e refazimento, está na variação das distâncias que os performers e espectadores tomam para se posicionar uns diante dos outros. Durante a maior parte dessa performance, os corpos se lançam num estar junto ritmado pelo barulho do bater das panelas, instalando furiosamente um ambiente carnavalesco para o qual é imprescindível confiar um no outro; uma confiança performática, que se dá em ação e pela dessacralização do corpo como única propriedade do "eu". O direito de ser corpo se junta à necessidade de produzir relações parciais, provisórias e igualmente intensas.

Batucada acontece no fora dos corpos dos performers, provocando, liberando e permitindo experimentar com o outro, o corpo de "qualquer um", na formação de um "nós gigante". E por isso é comum os espectadores deixarem suas posições de observadores e, muitas vezes se despirem, tornando-se agentes nessa prática coletiva. Há em Batucada um princípio de explosão que culmina na cena final de morte, para a qual não é possível olharmos indiferente à extravagância vital que the permitiu acontecer.

A brutalidade evidente da última cena indica uma leitura a contrapelo da performance: tudo o que até ali era festa, celebração, simulação de vitória e arraigamento social se transforma em impasse - cena de um impedimento causando embaraço pela contradição dos afetos convocados. Nas palavras de Evelin concedidas para uma entrevista (Cordeiro, 2019, p. 372), ele afirma: "Batucada é exatamente uma história que consiste em produzir a mistura de cinquenta pessoas, onde desaparecer pode ser vivido como um espaço de liberdade". Na Morte, de Gert, sentir-se viva e ter a liberdade de possuir o próprio corpo significa exercer a autonomia para excluir determinismos que vem de fora, e inventar o próprio ataque contra si, que é um movimento polivalente de dentrofora, de morte e de nascimento. Ela escreve:

E quando o meu cadáver voltar a ser pó, ele então, talvez, fará nascer, depois de bilhões de anos, uma flor ou uma folha de grama, a não ser que eu tenha me tornado uma minhoca. É isso. Mas é isso que eu não 
aceito. Eu quero me sentir eu mesma e ninguém mais, eu que quero me sentir, a mim²1. (Gert, 2004, p. 48).

A vontade de se sentir à si mesma revela o fundamento da morte como gesto dançando na peça de Gert: trata-se de intensificar uma conexão profunda com a própria interioridade, fazendo a sequência de movimentos emergir de um impulso interior que é a força vital para que a dança aconteça.

Faz parte da vitalidade de Gert et Evelin considerar o fora, habitar o vazio e o silêncio ficando distante da hipersignificação capitalista dos corpos, e portanto, conduzindo uma vida mais próxima de uma grande intensidade e concentração de energia canalizadoras dos movimentos aparentes.

\section{Considerações vitais}

Colocar à prova a tradução de um gesto coreográfico em uma aventura intelectual-sensível implica em fazer um cruzamento de mundos, intensificando uma certa plasticidade interpretativa em atribuir palavras àquilo que vemos, sentimos e pensamos. Uma sensibilidade política emerge na relação entre dança e morte no que ela oferece condições para pensar a viabilidade da vida, e a arte como operação transformadora das existências e seus destinos. Pensar a política com o pensamento coreográfico, hoje, é também olhar para as cenas que a arte constrói como maneiras de questionar o nosso estar vivo, o nosso morrer e o vaivém entre um e outro.

A dança, na localidade dessas duas obras, engaja maneiras de apresentar o condicionamento das vidas e as suas finitudes. Dançar é aqui correr o risco de se oferecer corporalmente diante de um perigo, ora simulado por um jogo fictício ora levado a cabo por uma ação direta. Para dançar essas duas peças, é preciso saber jogar com a perda de controle e se afastar da tirania da corporeidade perfeita,

\footnotetext{
${ }^{21}$ Et quand mon cadavre sera retourné à l'état à l'état de poussière, alors peut-être il donnera naissance, au bout de milliards d'années, à une fleur ou à un brin d'herbe, à moins que je ne sois devenue un ver de terre. Voilà tout. Mais c'est ce que je n'accepte pas. Je veux me sentir moi-même et personne d'autre, je veux me sentir, moi. (Tradução nossa)
} 
saudável, tônica, mas também asséptica e artificial. A gestualidade política que as duas obras abraçam está na escrita sensível das decisões tomadas por seus autores. A decisão que parece comum aos dois coreógrafos é de que a vida não está à toa, mas permanentemente condicionada às relações sociais que decidem da sua inteligibilidade. Se Gert tende mais à uma precariedade existencial enquanto Evelin investe uma precariedade social, ambos elaboram um projeto pela vida que é de fortalecer a sua inescapável exposição e incessante necessidade de cuidado.

Que uma identificação com formas políticas se faça mais imediatamente com Batucada e de modo mais latente com Morte, só nos serve para pensar que as formas escolhidas pelos artistas nunca são meras formas, mas inclinações sensíveis sujeitas a serem politizadas pelo olhar crítico e receptivo de quem entende a atividade do espectador como uma ação e uma disposição em conhecer. No contraste profícuo entre a proposição distanciada e individual de Gert e a frontal e coletiva de Evelin, observamos a dança politizar outras vitalidades nas relações com a morte. Contudo, tendo em vista que os corpos se ameaçam entre eles e se enlaçam pela potência de vida assim como pela manutenção da precariedade, as danças de Gert e Evelin lembram que estar vivo é um poder que não se tem sozinho.

Para terminar, uma citação de Florence Caeymaex (2019, p. 53), à partir do pensamento de Donna Haraway, sobre "viver e morrer com":

A continuidade ou a perseverança (ongoingness) é uma questão mais concreta, infinitamente mais pragmática que supõe "aceitar a mortalidade como condição da vida". Como viver e morrer bem, bem viver-com e morrer-com uns e com outros, sem esquecer, como sugere Vinciane Despret, a necessidade de solicitar para isso a co-presença viva dos ausentes - ainda mais nesses tempos de extinções massivas"22.

22 La continuité ou la persévérance (ongoingness) est une question beaucoup plus concrète, infiniment plus pragmatique, qui suppose d'"accepter la mortalité comme condition de la vie". Comment vivre et mourir bien, bien vivre-avec et mourir-avec les uns les autres, sans oublier, comme le suggère Vinciane Despret, la nécessité de solliciter pour ce faire la coprésence vivante des absents - d'autant plus en ces temps d'extinctions massives. (Tradução nossa). 


\section{Referências}

BUTLER, Judith. Ce qui fait une vie: essai sur la violence, la guerre et le deuil. Paris: Editions La Découverte, 2010.

CAEYMAEX, Florence. Introduction. Des cyborgs au Chthululucène. In: CAEYMAEX, Florence; DESPRET, Vinciane; PIERON, Julien (org). Habiter le trouble avec Donna Haraway. France: Éditions Dehors, 2019.

CORDEIRO, Volmir Gionei. Où le marginal danse: retours sur six pièces chorégraphiques. Saint-Denis, 2019. Tese (Doutorado) - Departamento Dança da Universidade Paris VIII, 2019.

EVELIN, Marcelo. Batucada. Disponível em: https://www.demolitionincorporada.com/batucada

EVELIN, Marcelo. Ovo - performance-conferência. Disponível em: https://www.demolitionincorporada.com/ovo

GERT, Valeska. Je suis une sorcière: kaléidoscope d'une vie dansée. Paris: Éditions Complexe et Centre National de la Danse, 2004.

IVERNEL, Philippe, Introduction Le phénomène Valeska Gert. In: GERT, Valeska. Je suis une sorcière: kaléidoscope d'une vie dansée. Paris: Éditions Complexe et Centre National de la Danse, 2004.

KUNIICHI, Uno, As pantufas de Artaud segundo Hijikata. In: GREINER, Christine; AMORIN, CLaudia (org). Leituras da Morte. São Paulo: Annablume, 2007.

LAUNAY, Isabelle, Le cine-geste de Valeska Gert. In: BOULBĖS, Carole. Femmes, attitudes performatives. Paris: Les presses du réel, 2014.

MBEMBE, Achille. Necropolítica: biopoder, soberania, estado de exceção, política da morte. Tradução de Renata Santini. São Paulo: N-1 Edições, 2018.

VIANA, Ana Cláudia Albano; DA NÓBREGA, Terezinha Petrúcia. Conversas sobre morte e dança: os fios tramados por Thanatos e Terpsícore. Revista Brasileira de Estudos da Presença. vol.9 no.4 Porto Alegre 2019. Epub Oct 10, 2019.

Disponível em https://www.scielo.br/scielo.php?script=sci arttext\&pid=S223726602019000400303\&lng=en\&nrm=iso\&tlng=pt\#fn6. Acesso em: 03 jun. 2020. 
Recebido em: 29/06/20

Aprovado em: 29/09/20

Universidade do Estado de Santa Catarina - UDESC

Programa de Pós-Graduação em Teatro - PPGT

Centro de Arte - CEART

Urdimento - Revista de Estudos em Artes Cênicas

Urdimento.ceart@udesc.br 